\title{
A Case Study of Thaumasite Sulfate Attack in Tunnel Engineering
}

\author{
Chongbang Xu, Xingyu Zhou $(\mathbb{D}$, Hualao Wang, Xiaojing Gao $\mathbb{D}$, and Xuefeng Li \\ Research Institute of Highway Ministry of Transport, Bridge \& Tunnel Research Center, Beijing 100088, China \\ Correspondence should be addressed to Xingyu Zhou; z19980131@gmail.com
}

Received 27 April 2021; Accepted 9 November 2021; Published 6 December 2021

Academic Editor: Chunyang Zhang

Copyright ( $\odot 2021$ Chongbang Xu et al. This is an open access article distributed under the Creative Commons Attribution License, which permits unrestricted use, distribution, and reproduction in any medium, provided the original work is properly cited.

There existed ever-increasing structural diseases in the Dugongling tunnel after the completion of the construction. Systematic research was carried out based on the information of tunnel engineering geology, disease development, mineral composition of surrounding rock and concrete, and laboratory tests. Results showed that (1) the concrete structure from the Dugongling tunnel suffered from a typical thaumasite sulfate attack (TSA); (2) tunnel diseases developed under the influence of multiple geological factors such as groundwater, karst, gypsum bearing stratum, and geological tectonics. Groundwater aggravated the appearance of engineering defects of various geological factors and accelerated the softening and swelling of surrounding rock. Moreover, the additional load of supporting structure increased, and the concrete structure was prone to sulfate attack; (3) the development of tunnel diseases showed long-cycle and large-scale characteristics, and the types of diseases are heterogeneous. The tunnel diseases develop rapidly in the third year after the construction. The structure collapse disease, one of the most serious diseases of tunnel lining, occurred in the fifth year after construction; and (4) according to the conditions of TSA, technical treatment measures were proposed. These measures included blocking the flow of $\mathrm{CO}_{3}^{2-}$, improving the impermeability of concrete structures, and decreasing the diffusion of external ions and groundwater. This work provides a solution for the treatment of similar tunnel disease and mechanism analysis.

\section{Introduction}

The gypsum rock in the carbonate rock area has multiple influences on the stability of the tunnel. The gypsum rock can not only cause dissolution combined with the co-deposited carbonate minerals [1], but also soften and swell under the action of groundwater [2-4]. Moreover, gypsum rock can lead to sulfate attacks in the lining concrete structures [5-9], whereas the thaumasite sulfate attack (TSA), elusive, is relatively late understood by researchers. The formation mechanism of TSA is unclear yet $[10,11]$. TSAs in tunnels have occurred in Switzerland, Germany, Norway, and Australia [12-15], while these attacks are more common in water conservancy dam projects [16-18] in China. The reports on TSA in Chinese tunnel projects are extremely rare. TSA may dissolve the main hydration products of Portland cement, CSH gel, in concrete tunnel lining. The decomposition of $\mathrm{CSH}$ gel leads to the decrease in the bearing capacity of the tunnel lining structure and the reduction in structural safety and reliability $[19,20]$, which is one of the most harmful types of tunnel diseases.
Hazardous engineering conditions caused extremely serious diseases and TSAs in the tunnel supporting and lining structure after construction. Based on the analyses of sulfate erosion conditions and softening and swelling characteristics of surrounding rock, comprehensive tests of the mineral composition of surrounding rock and lining concrete and systematic analyses of the types and development rules of tunnel diseases were carried out to figure out the formation process of diseases in the Dugongling tunnel. Finally, a targeted engineering treatment plan was put forward to effectively treat the diseases. In addition, this kind of treatment provides a reference plan for the tunnel with TSAs.

\section{Project Overview}

The Dugongling tunnel [21] is a separated two-way four-lane highway tunnel. The starting and ending pile number of left line is from $\mathrm{ZK} 33+226$ to $\mathrm{ZK} 35+700$ with a length of $2474 \mathrm{~m}$ and that of right line is from YK33 + 227 to YK35 + 742 with a length of $2515 \mathrm{~m}$; the overall direction of 
tunnel axis is $264^{\circ}$, and the maximum depth of tunnel is $231 \mathrm{~m}$. The construction clearance of the tunnel has a net width of $10.25 \mathrm{~m}$ and a height limit of $5 \mathrm{~m}$ (see Figure 1).

The Dugongling tunnel was completed in November 2012. Tunnel disease was first detected in the later stage of its construction. As of 2016, the total length of the tunnel structure that needed to be demolished and replaced due to diseases is $1,515 \mathrm{~m}$. The main range of tunnel diseases occurred in sections from $\mathrm{K} 34+500$ to $\mathrm{K} 34+800$. Diseases in the Dugongling tunnel were mostly lining concrete cracking, and deformation at early stage of the diseases, no corrosion, and argillization phenomena of concrete were found. The concrete argillization phenomenon had not been discovered until the firebox was removed, as shown in Figure 2. Concrete argillization showed a feature of integrity in the dry environment, while seemed sludge-like under grasping in the wet.

In the supplementary survey of tunnel diseases in 2016, 223 samples from 119 cross-sectional primary support concrete were picked. The mineral compositions of the concrete were mainly calcite, dolomite, quartz, potash feldspar, plagioclase, ettringite, gypsum, and thaumasite. 60 sections of the 119 sections were detected with TSA, accounting for $50.4 \%$ of total samples; 84 of 223 samples of primary supporting concrete were detected with thaumasite (Figure 3), accounting for $37.7 \%$ of total samples. It can be seen that the disease in the Dugongling tunnel was a typical case of TSA [22].

\section{Tunnel Disease Characteristics and Sulfate Attacks}

\subsection{Scale and Extent of Diseases}

3.1.1. Main Types of Tunnel Diseases. The types of diseases in the Dugongling tunnel, listed in Table 1, show an increasing trend in previous years. In 2012, the main kinds of tunnel diseases were lining cracking, pavement uplifting, and cracking. In 2013, the overturning of the cable trench was detected; in 2014, the staff found partial cracks at arch footing and intrusion of the clearance in some sections, as shown in Figure 4; and in 2016 and 2017, the diseases of the Dugongling tunnel deteriorated, leading to the collapse and fall of the secondary lining concrete (Figure 5) and the extrusion and damage of the inner wall of the cable trench (Figure 6).

3.1.2. Scales in Previous Years. The disease scales over the years are shown in Figure 7. The disease scale of the tunnel reached $2321 \mathrm{~m}$ at the beginning of 2017, which accounted for $47 \%$ of the length of the tunnel. It can be seen from Figure 7 that the fastest development period of tunnel diseases took place in 2013 and 2014, $1765 \mathrm{~m}$, which accounted for $76 \%$ of total length of diseases; there was a gradual increase in new diseases from 2015 to 2017. The length of new diseases was only $8 \mathrm{~m}$ and $58 \mathrm{~m}$ in 2016 and 2017, respectively. Thus, the scale of tunnel disease developed rapidly in the early stage of development of disease, and the growth rate of the total diseases slowed down in the later stage.

3.1.3. Degree of Disease Development. According to the classification of disease levels from technical specification of maintenance for highway tunnel (JTG H12-2015), the variations of disease scales over the years at all levels are shown in Figure 8.

(i) The number of Level 1 (i.e., the tunnel structure is in serviceability and safety) and Level 2 (i.e., no negative effect on the traffic safety of tunnel vehicles, and further observation is needed) diseases in the tunnel decreased from 2014 to 2017, and the reductions in Level 1 and Level 2 were $66 \mathrm{~m}$ and $70 \mathrm{~m}$, respectively.

(ii) The number of Level 3 and Level 4 diseases fluctuated from 2014 to 2017, indicating that tunnel diseases were developing dynamically during this period.

(iii) The number of tunnel sections with Level 5 diseases has gradually increased in the 3 years, with an increasing rate of $86 \%$ and a length of $215 \mathrm{~m}$, of which the fastest development occurred in 2014 to 2015 and 2015 to 2016. There was an increase in more than 80 m per year in 2014 to 2015 and 2015 to 2016, respectively.

(iv) By the year when diseases began to be resolved, 2017, the total scale of Level 3, Level 4, and Level 5 diseases in need of treatment reached $1515 \mathrm{~m}$.

3.1.4. Typical Cross-Sectional Cases. The design basis of YK34+ 482 YK34+524 section is grade IV surrounding rock. The primary supporting of the tunnel is I16 I steel with a spacing of $1.0 \mathrm{~m}$ and C20 concrete with a thickness of $20 \mathrm{~cm}$, and the secondary lining of the tunnel is C25 plain concrete with a thickness of $40 \mathrm{~cm}$; a fire chamber is set on the right side of YK34+500 section. The development process of disease is as follows:

(1) The process of collapse. During the construction safety inspection in March 2017, cracks around the fire chamber were discovered; the monitoring data in April showed that the length and width of the diagonal cracks on the upper left side of the fire chamber increased, extending upward from the spandrel; cracks continued to develop in May and June, and a small area of concrete surface peeling occurred; in July, the concrete collapsed suddenly (Figure 9).

(2) Description of the surrounding rock. The concrete in the internal side of the fire chamber showed that the internal (secondary lining and primary supporting) concrete expanded and deformed outwards about $5 \mathrm{~cm}-10 \mathrm{~cm}$, showing a "belly bulging" shape (Figure 10); the expansion of the waterproof board, after the collapse of concrete, was particularly obvious, 


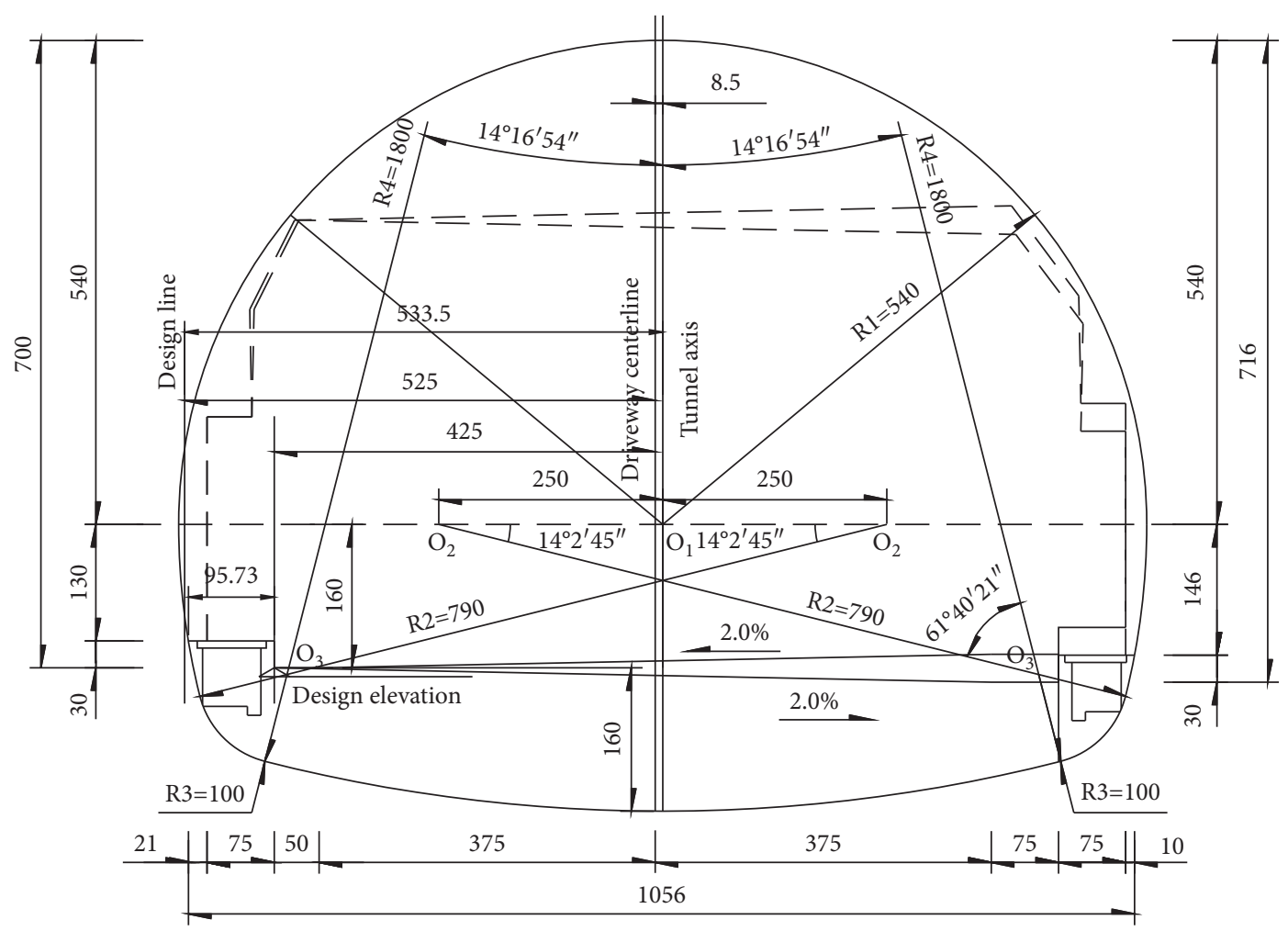

Figure 1: Interior outline design of the Dugongling tunnel (unit: $\mathrm{cm}$ ).
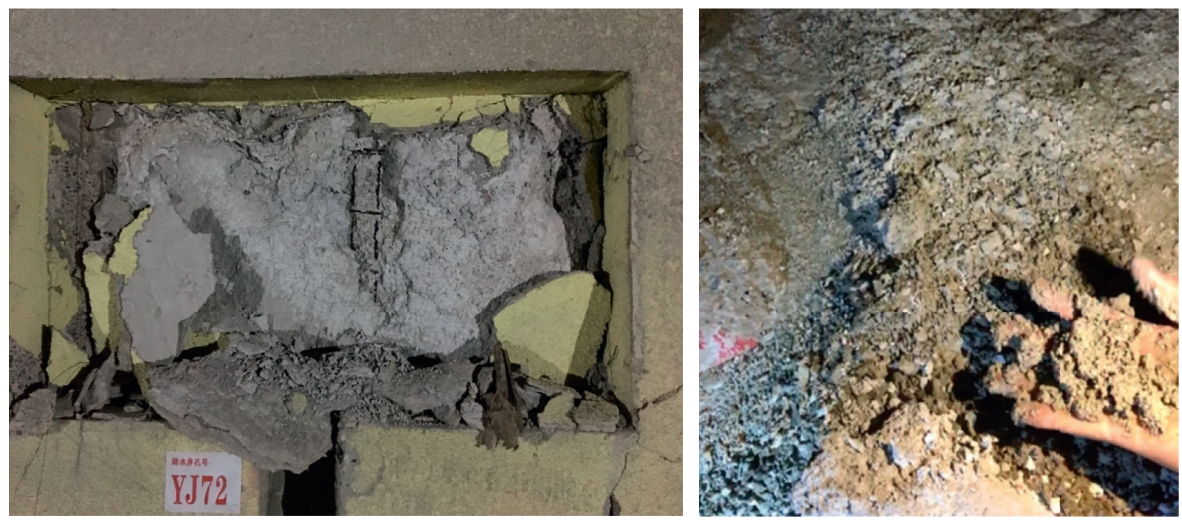

Figure 2: Photographs of the corroded tunnel lining concrete.

and the primary supporting concrete behind it showed damp and sandy features.

(3) Indoor testing. The surrounding rock and concrete there were sampled and sent for compositional analysis. The results showed that the surrounding rock was gypsum rock with gypsum content of $97 \%-$ 98\% (Figure 11 and Table 2); the thaumasite content in the primary supporting concrete was $19.3 \%$, and the contents of gypsum and ettringite were $17.1 \%$ and $3.8 \%$, respectively.

\section{Geological Cause Analysis of Tunnel Diseases}

Thaumasite sulfate attack is a special type of sulfate attack. The formation of TSA needs slow temperature (below $15^{\circ} \mathrm{C}$ ), water, $\mathrm{SO}_{4}^{2-}, \mathrm{CO}_{3}^{2-}, \mathrm{Si}^{4+}, \mathrm{SiO}_{3}^{2-}, \mathrm{Ca}^{2+}$, etc. The following analyses of the causes of the diseases in the Dugongling tunnel are based on the formation conditions of thaumasite sulfate attack.

4.1. Low Temperature. The tunnel sites in a temperate semiarid continental climate area. The temperature of this area is between $-5.9^{\circ} \mathrm{C}$ and $23^{\circ} \mathrm{C}$, and the average temperature of this area is $9.2^{\circ} \mathrm{C}$. The temperature in the five months from November to March of the following year is below $10^{\circ} \mathrm{C}$; the temperature inside the tunnel ranges from $-5^{\circ} \mathrm{C}$ to $20^{\circ} \mathrm{C}$ throughout the year, with an average temperature of $8.8^{\circ} \mathrm{C}$. Therefore, the environment of the tunnel lining concrete structure provides low-temperature conditions for TSA. 


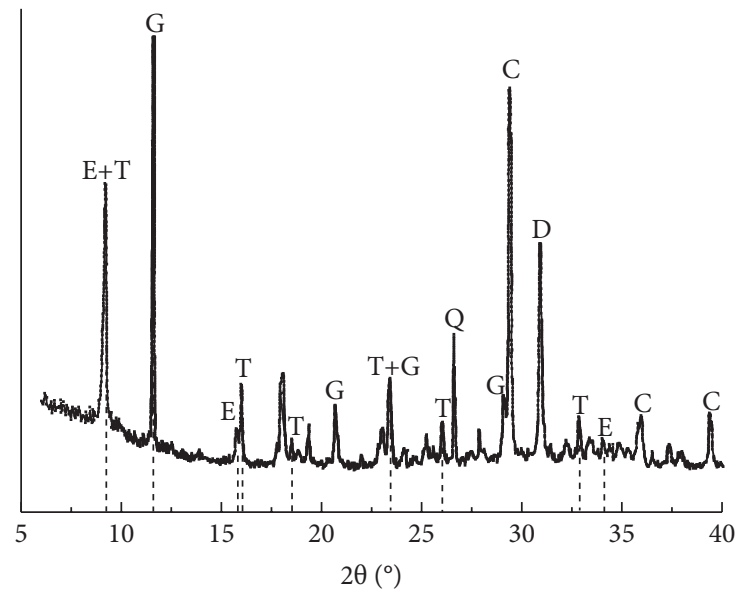
T: Thaumasite
C: Calcite
E: Ettringite
G: Gypsum
Q: Quartz
D: Dolomite

FIgURE 3: XRD pattern of tunnel lining concrete sample [22].

TABle 1: Tunnel disease types over the years [23].

\begin{tabular}{|c|c|c|c|c|c|c|c|c|}
\hline Years & $\begin{array}{l}\text { Cracking of } \\
\text { the lining }\end{array}$ & $\begin{array}{l}\text { Uplift of the } \\
\text { pavement }\end{array}$ & $\begin{array}{c}\text { Cracking of } \\
\text { the } \\
\text { pavement }\end{array}$ & $\begin{array}{l}\text { Overturning of } \\
\text { the cable trench }\end{array}$ & $\begin{array}{l}\text { Local } \\
\text { bursting } \\
\text { crack }\end{array}$ & $\begin{array}{c}\text { Deformation } \\
\text { invading limit }\end{array}$ & $\begin{array}{l}\text { Cracking of the } \\
\text { secondary } \\
\text { lining }\end{array}$ & $\begin{array}{l}\text { Extrusion of the } \\
\text { inner wall of the } \\
\text { cable trench }\end{array}$ \\
\hline 2012 & $\sqrt{ }$ & $\sqrt{ }$ & $\sqrt{ }$ & & & & & \\
\hline 2013 & $\sqrt{ }$ & $\sqrt{ }$ & $\sqrt{ }$ & $\sqrt{ }$ & & & & \\
\hline 2014 & $\sqrt{ }$ & $\sqrt{ }$ & $\sqrt{ }$ & $\sqrt{ }$ & $\sqrt{ }$ & $\sqrt{ }$ & & \\
\hline 2015 & $\sqrt{ }$ & $\sqrt{ }$ & $\sqrt{ }$ & $\sqrt{ }$ & $\sqrt{ }$ & $\sqrt{ }$ & & \\
\hline 2016 & $\sqrt{ }$ & $\sqrt{ }$ & $\sqrt{ }$ & $\sqrt{ }$ & $\sqrt{ }$ & $\sqrt{ }$ & $\sqrt{ }$ & $\sqrt{ }$ \\
\hline 2017 & $\sqrt{ }$ & $\sqrt{ }$ & $\sqrt{ }$ & $\sqrt{ }$ & $\sqrt{ }$ & $\sqrt{ }$ & $\sqrt{ }$ & $\sqrt{ }$ \\
\hline
\end{tabular}
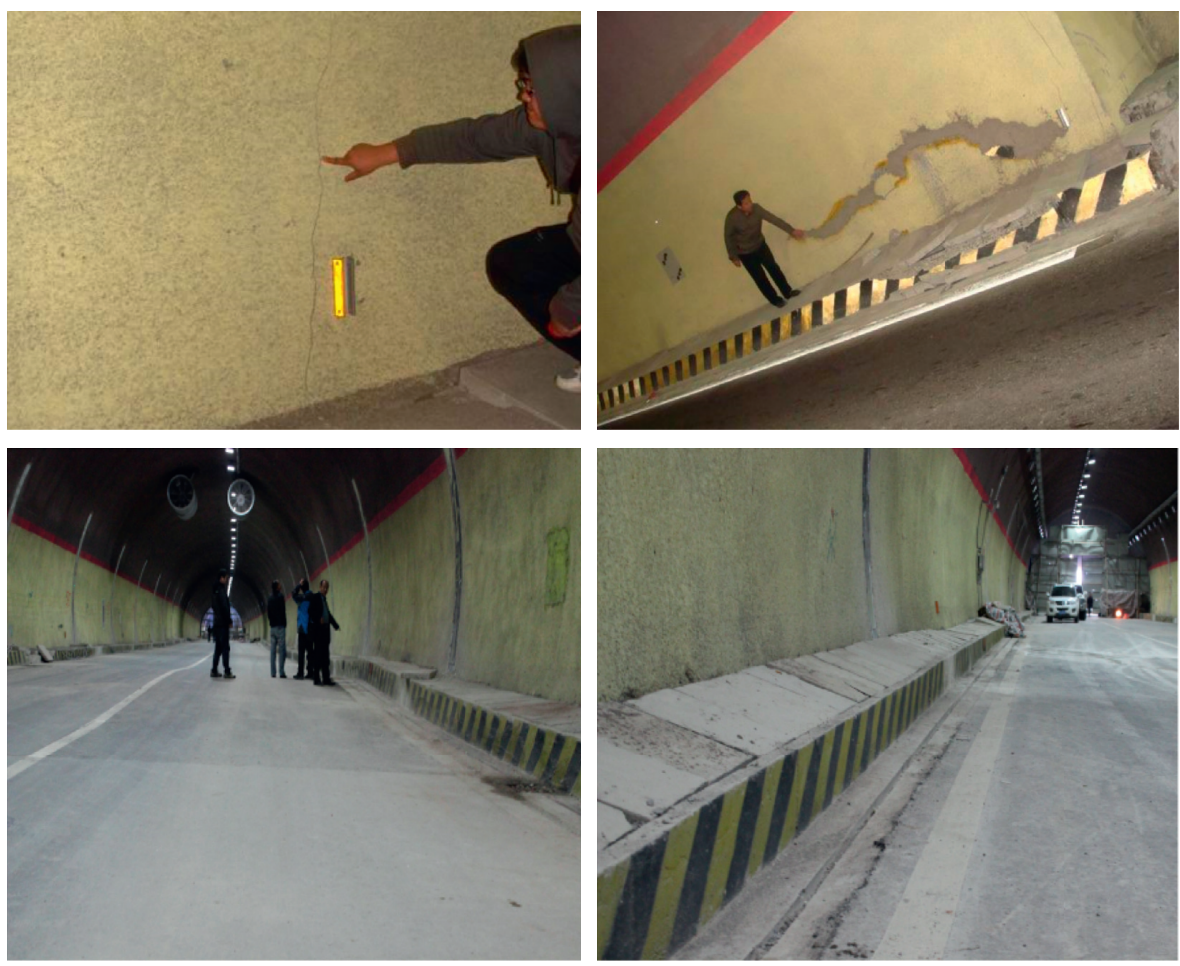

Figure 4: Photograph of early-stage tunnel disease. 


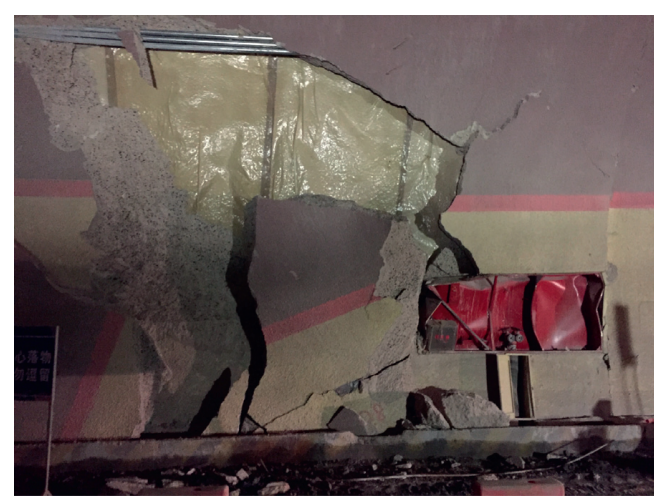

Figure 5: Sudden collapse of the secondary tunnel lining.

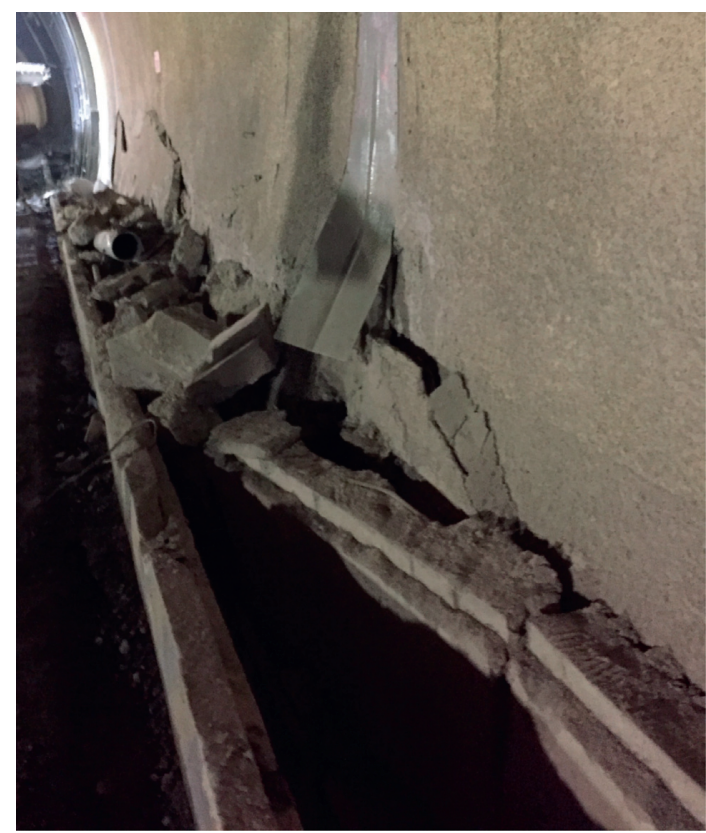

FIgURE 6: Inner wall extrusion of the cable trench.

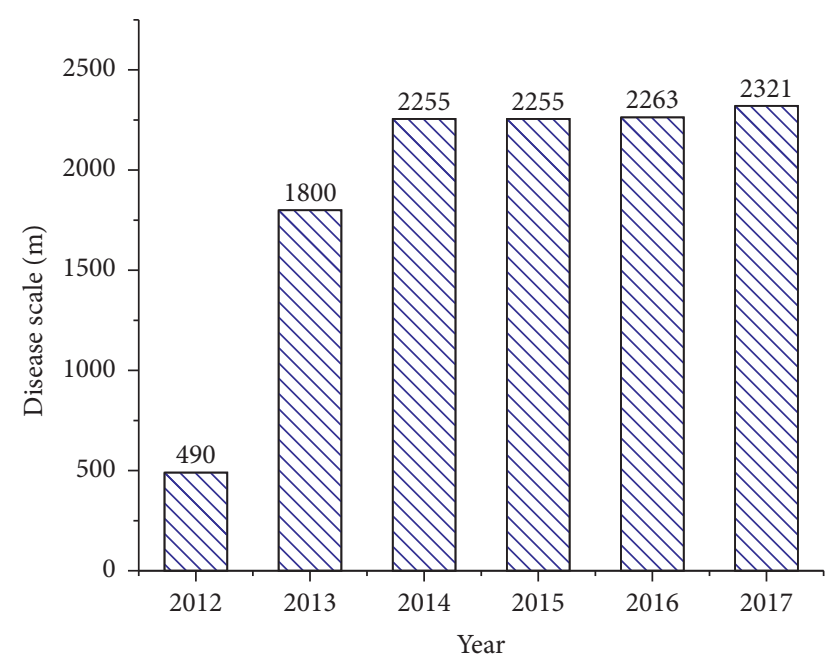

Figure 7: Disease statistics in previous years of the Dugongling tunnel [23].

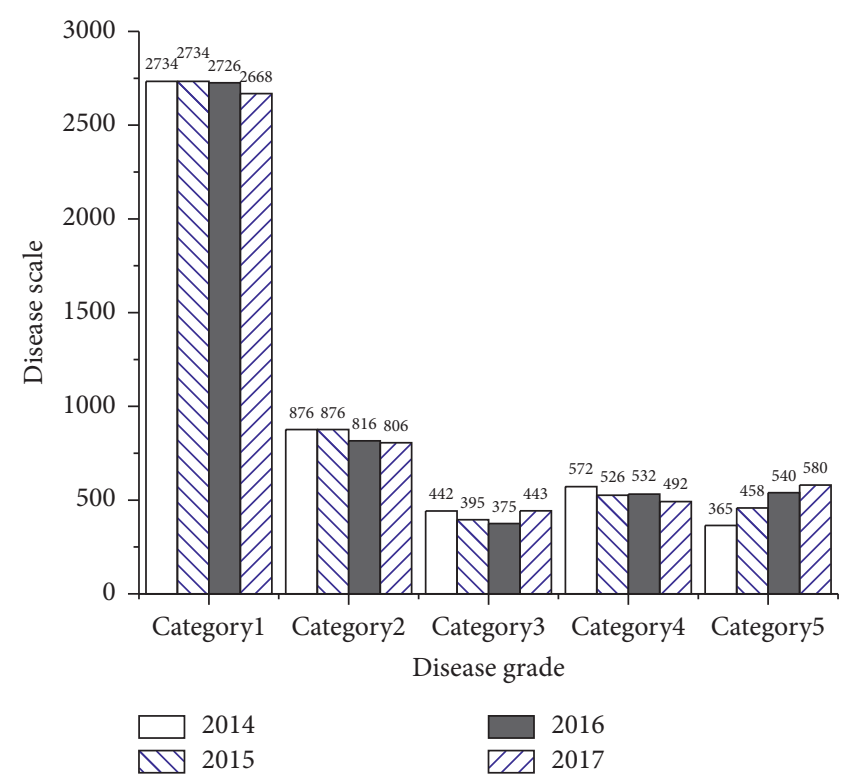

FIGURE 8: Annual variations of disease scale of different levels [23].

\subsection{Groundwater}

4.2.1. Type of Groundwater. The types of groundwater in the tunnel site area are carbonate fissure karst water and perched water, of which the water level of carbonate fissure karst water is lower than the design elevation of the tunnel. Therefore, this type of groundwater has little effect on the diseases of the Dugongling tunnel. The perched water, mainly replenished by atmospheric precipitation, has a large seasonal variation.

4.2.2. Supplement of Groundwater. The annual average precipitation in the tunnel site area is $592.33 \mathrm{~mm}$ and its main precipitation period is from July to September, which accounts for $56 \%$ to $70 \%$ of the annual precipitation. Affected by topography, surface precipitation collects and infiltrates along the mountain to low-lying places. In section $\mathrm{K} 34+500 \sim \mathrm{K} 34+800$ of the tunnel, more than 100 iron ore pits distribute on the surface and its cross sections of the pits vary in size, and the shapes are mostly bands and ellipses (Figure 12) according to the surface survey. The group of surface mine pits provides conditions for surface water collection and irrigation. It is estimated that the surface water infiltration within the mine pits reaches $31 \mathrm{~m}^{3} / \mathrm{d}$.

After the surface water infiltrates, it circulates along the internal cracks and pores in the rock mass. The dissolution and development conditions of the tunnel rock mass provide a path for this circulation. According to engineering survey data and tunnel construction information, there are many joints, cracks, and dissolution in the surrounding rock of the tunnel, and the dissolution of the tunnel site shows a typical characteristic of combined carbonate and sulfate erosions [24, 25]. Most of the dissolution is dissolution pores, channels (Figure 13), and small karst caves (Table 3). Moreover, due to the 


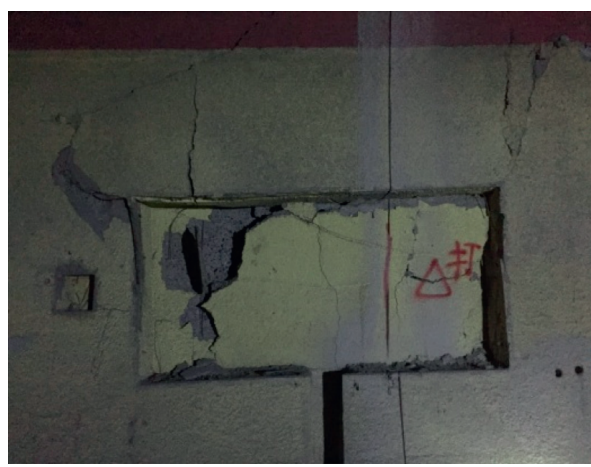

(a)

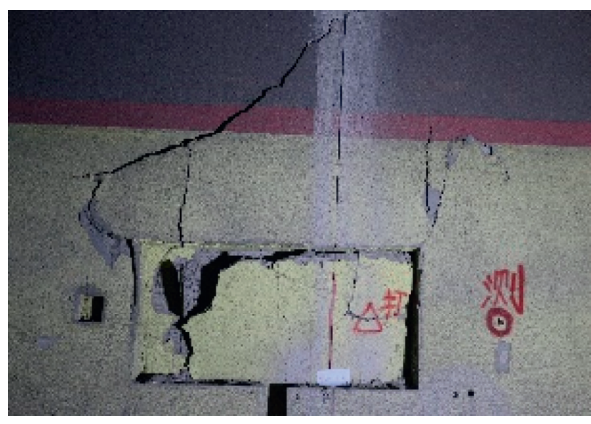

(c)

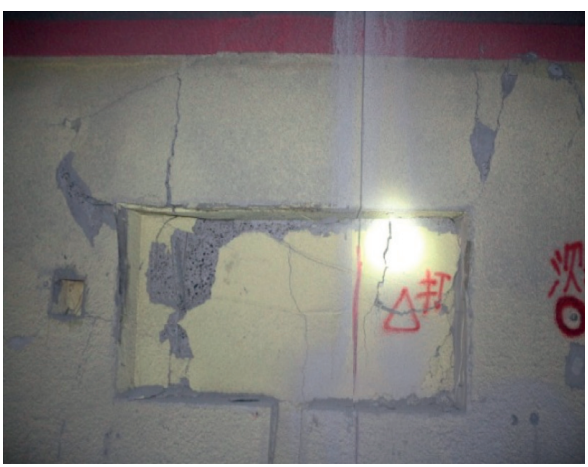

(b)

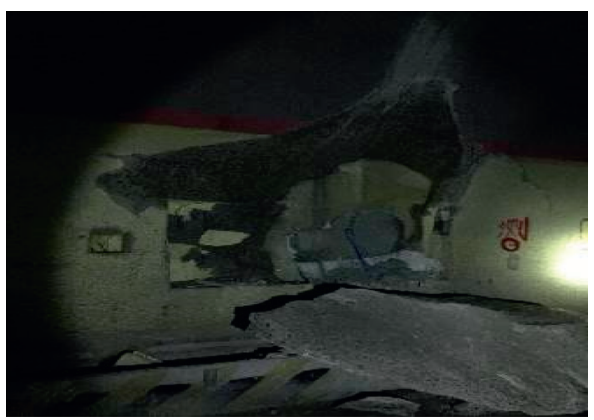

(d)

Figure 9: Disease development process of the fire chamber in YK34+500. (a) 2017.03. (b) 2017.04. (c) 2017.05. (d) 2017.07.
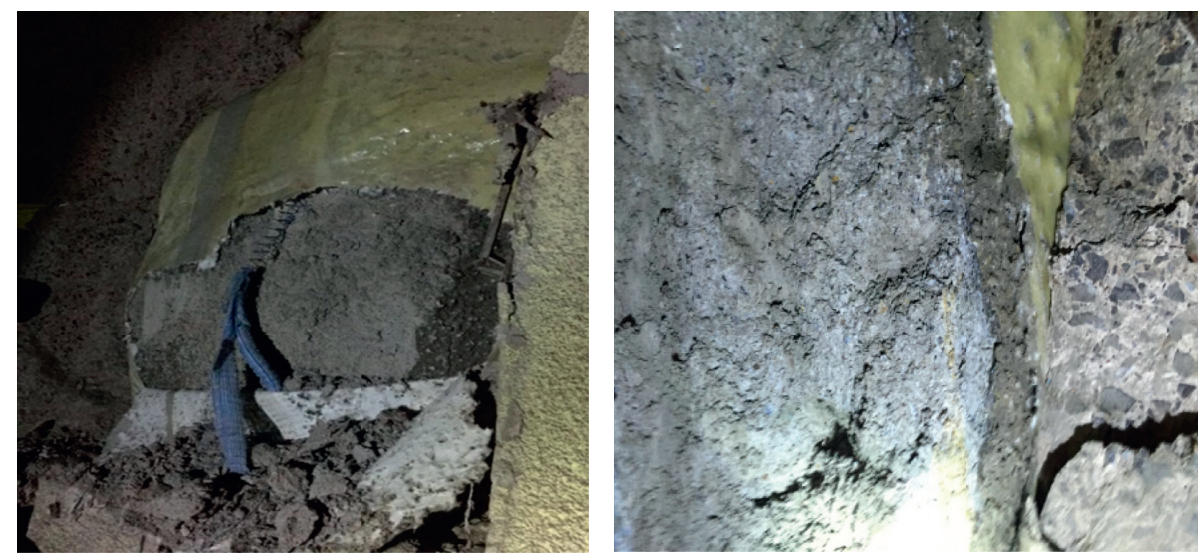

FIGURE 10: Photographs of concrete in the field of YK34 +500 .
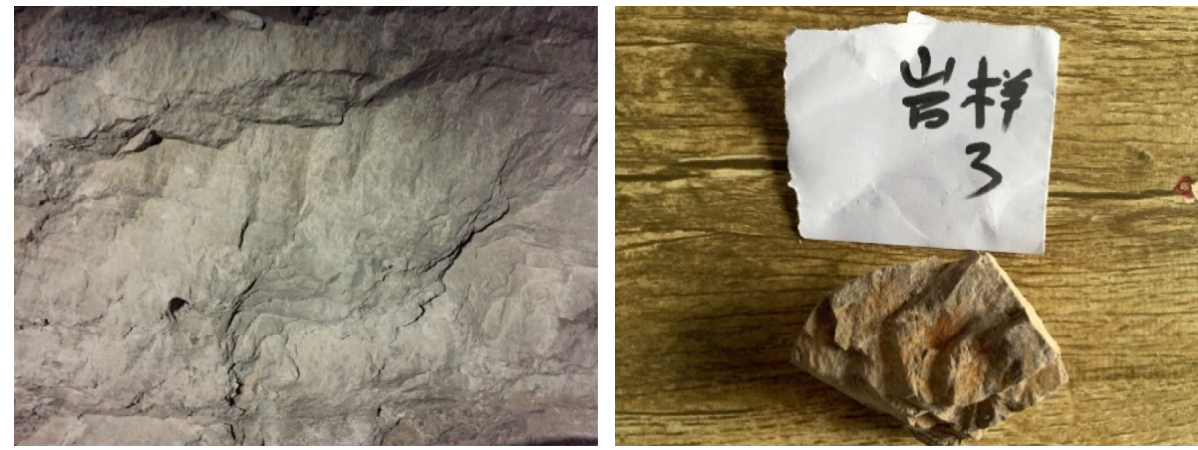

FIGURE 11: Surrounding rock exposure and rock sample photographs in YK34+500. 
TABLE 2: Identification results of surrounding rock samples in section YK34 +500 .

\begin{tabular}{|c|c|c|}
\hline No. & Test items & Test results/descriptions \\
\hline 1 & Name of rock sample & Gypsum rock \\
\hline 2 & $\begin{array}{c}\text { Naked-eye observation on } \\
\text { color }\end{array}$ & Grey-white \\
\hline 3 & Sample preparation & Thin slice \\
\hline 4 & Structure & Granular structure \\
\hline 5 & Tectonics & Lump \\
\hline 6 & Identification basis & GB/T17412.1 \\
\hline 7 & Essential mineral & 97\%-98\% gypsum \\
\hline 8 & Secondary minerals & $2-3 \%$ dolomite \\
\hline 9 & Accessory mineral & Apatite \\
\hline 10 & Microscopic observation & $\begin{array}{l}\text { The rock has lump tectonics and a granular structure. } \\
\text { Gypsum is tabular and colorless with a particle size distribution of } 0.01-2.0 \mathrm{~mm} \text { and has a negative } \\
\text { protrusion. The highest interference color is first-order yellow and white, and cleavage in one direction } \\
\text { is observed. } \\
\text { Dolomite has a semi-automorphic rhombohedral shape with a particle size distribution of } 0.01-0.03 \mathrm{~mm} \\
\text { and is unevenly distributed. It has a prominent flash protrusion and high-order white interference color. }\end{array}$ \\
\hline
\end{tabular}
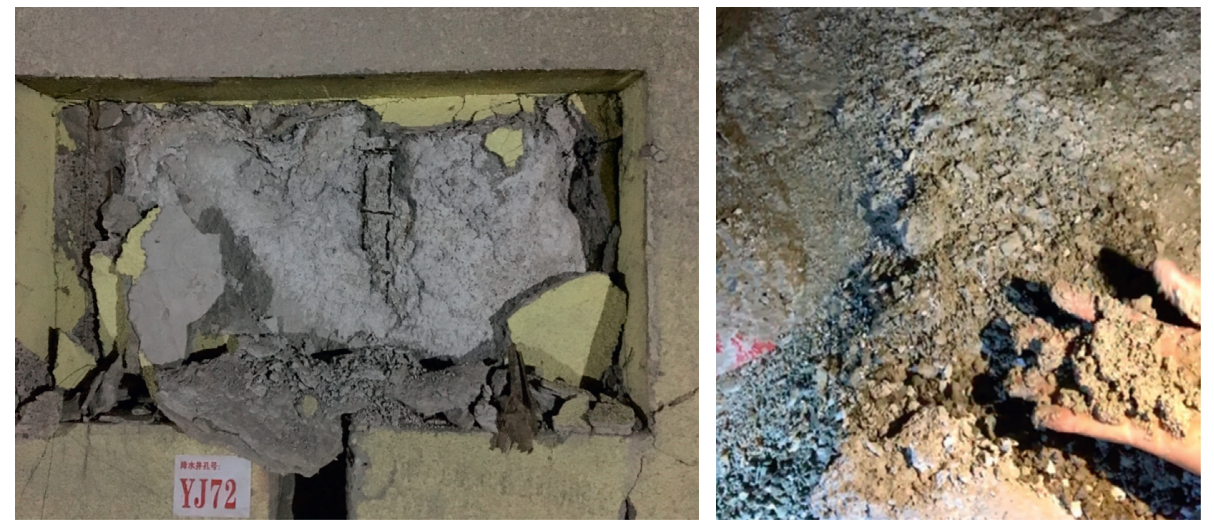

Figure 12: Photographs of the corroded tunnel lining concrete.

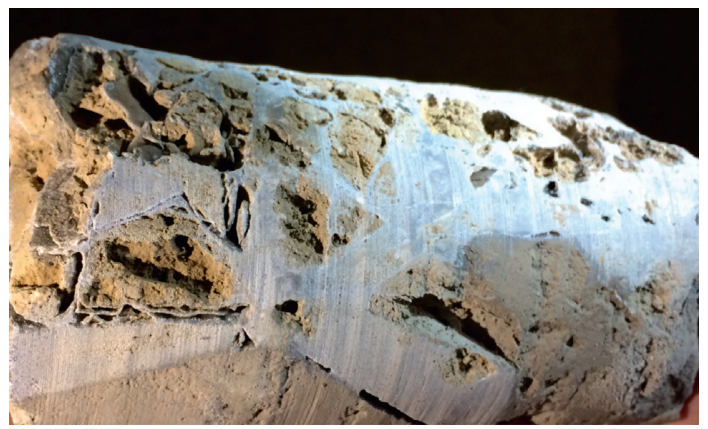

Figure 13: Dissolution of rock core sample in the field.

interconnection between the dissolution pores the air blow in the tunnel drilling is observed (Figure 14).

\subsubsection{The Collection of Groundwater around the Tunnel.} In the process of groundwater circulation in the rock mass, the groundwater accumulates in some sections due to the influence of the geological structure. The compound folded structure is in the $\mathrm{K} 34+900-\mathrm{K} 35+200$ section of the cave body, consisting of two synclines $(S 1, S 3)$ and one anticline
(S2) and striking nearly the north-south direction: the $S 1$ syncline crosses the tunnel at an angle of $84^{\circ}$, the east wing occurrence is $200^{\circ} \angle 5^{\circ}$, and the west wing occurrence is $122^{\circ} \angle 25^{\circ}$; S2 syncline crosses the tunnel at $88^{\circ}$ obliquely, the east wing occurrence is $122^{\circ}<25^{\circ}$, and the west wing occurrence is $280^{\circ}<20^{\circ}$; and $S 3$ syncline crosses the tunnel at $72^{\circ}$, the east wing occurrence is $280^{\circ}<20^{\circ}$, and the west wing occurrence is $80^{\circ}<4^{\circ}$. In the composite fold structure section of the tunnel, the surrounding rock below the sidewall is mainly marl, which has a strong water barrier effect. The 
TABLE 3: Information of partial caves in the Dugongling tunnel.

\begin{tabular}{|c|c|c|c|c|c|c|c|c|c|}
\hline No. & Pile no. & Location & Scale & Photograph & No. & Pile no. & Location & Scale & Photograph \\
\hline 1 & YK34 + 796 & $\begin{array}{l}\text { Arch } \\
\text { crown }\end{array}$ & $\begin{array}{l}\text { The length, } \\
\text { width, and } \\
\text { height are } 10 \mathrm{~m} \text {, } \\
3.5 \mathrm{~m} \text {, and } 4 \mathrm{~m} \text {, } \\
\text { respectively }\end{array}$ & & 4 & ZK35 + 060 & $\begin{array}{l}\text { Arch } \\
\text { crown }\end{array}$ & $\begin{array}{l}\text { The length, } \\
\text { width, and } \\
\text { height are } 6 \mathrm{~m} \text {, } \\
6 \mathrm{~m} \text {, and } 1.7 \mathrm{~m} \text {, } \\
\text { respectively }\end{array}$ & \\
\hline 2 & ZK34 + 308 & $\begin{array}{c}\text { Left } \\
\text { spandrel }\end{array}$ & $\begin{array}{l}5 \mathrm{~m} \text { long, } 1 \mathrm{~m} \\
\text { width, } 1 \mathrm{~m} \\
\text { height } \\
\text { The length, } \\
\text { width, and } \\
\text { height are } 5 \mathrm{~m} \text {, } \\
1 \mathrm{~m} \text {, and } 1 \mathrm{~m} \text {, } \\
\text { respectively }\end{array}$ & & 5 & ZK35 + 302 & $\begin{array}{c}\text { Right } \\
\text { spandrel }\end{array}$ & $\begin{array}{l}\text { The length, } \\
\text { width, and } \\
\text { height are } 4.8 \mathrm{~m} \text {, } \\
7.2 \mathrm{~m} \text {, and } 3.2 \mathrm{~m} \text {, } \\
\text { respectively }\end{array}$ & \\
\hline 3 & ZK34 + 703 & $\begin{array}{l}\text { Arch } \\
\text { crown }\end{array}$ & $\begin{array}{l}\text { The length, } \\
\text { width, and } \\
\text { height are } 4 \mathrm{~m} \text {, } \\
5 \mathrm{~m} \text {, and } 1.5 \mathrm{~m} \text {, } \\
\text { respectively }\end{array}$ & & 6 & ZK35 + 248 & $\begin{array}{l}\text { Arch } \\
\text { crown }\end{array}$ & $\begin{array}{l}\text { The length, } \\
\text { width, and } \\
\text { height are } 3 \mathrm{~m} \text {, } \\
2 \mathrm{~m} \text {, and } 3 \mathrm{~m} \text {, } \\
\text { respectively }\end{array}$ & \\
\hline
\end{tabular}

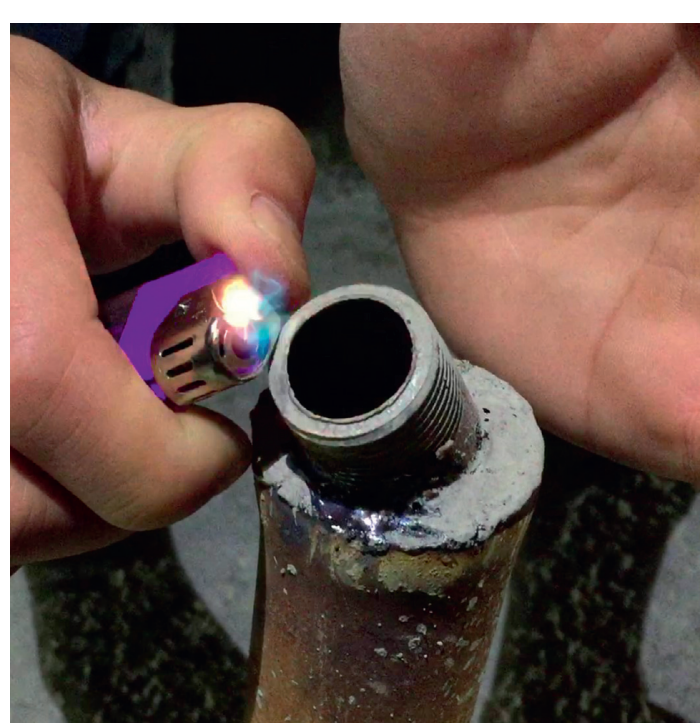

FIgURe 14: Air blow in the drilling.

coexistence of the two causes the concentration and occurrence of groundwater around the tunnel of the $S 1$ and $S 3$ syncline structure.

Based on the above analyses, surface precipitation flows along the surface and forms a pool at the mine pit, and flows down into the rock mass. Meanwhile, dissolved pores, caves, and small caves are the main paths for groundwater to circulate in the rock mass; groundwater converges around the tunnel under the influence of compound folded structure and marl, which provides the water for the formation of thaumasite sulfate attack.

4.3. Source of $\mathrm{SO}_{4}^{2-}, \mathrm{CO}_{3}^{2-}$, and $\mathrm{SiO}_{3}^{2-}$. The tunnel concrete is ordinary Portland cement. The calcium and silicon substances in this type of cement provide a large amount of $\mathrm{SiO}_{3}^{2-}$ and $\mathrm{Ca}^{2+}$ during the hydration reaction.
Therefore, the $\mathrm{SiO}_{3}^{2-}$ and $\mathrm{Ca}^{2+}$ come from concrete the tunnel used.

The tunnel line mainly locates in the interbedded formation of limestone and marlstone of the upper Majiagou Formation in the Middle Ordovician. The roof of the tunnel is a formation of limestone, and the bottom is an interbedded formation of marlstone and limestone. The geological lithology of the tunnel site provides $\mathrm{SO}_{4}^{2-}$ and $\mathrm{CO}_{3}^{2-} .30 \%$ of the 225 rock samples contain anhydrite or gypsum; $34 \%$ of the 121 sections contain anhydrite or gypsum. In the surrounding rock, gypsum rock is sandwiched in marlstone and is produced in layered and lenticular forms (Figure 15). The color of gypsum rock, similar to that of marlstone, is grey-white in general and grey-brown in parts (Figure 16), and the maximum content of gypsum rock in some rock samples is more than $90 \%$ (Table 2).

4.4. Other Reasons. In addition to the TSA, the softening and swelling characteristics of the surrounding rock contributed to the terrible disease in the Dugongling tunnel. The formation of marl has the properties of softening and swelling, and marl mechanical test report is listed in Table 4. Identification results of core samples of the surrounding rock are shown in Table 5. The softening coefficient of marlstone is $0.72 \sim 0.818$, the free expansion rate is $0.001-0.094$, the expansion force $\mathrm{Pp}$ varies from 0.99 to $20.6 \mathrm{kPa}$, and the saturated water absorption rate is $2.9 \sim 6.0 \%$. It shows that the marlstone from the Dugongling tunnel has the characteristics of water absorption softening and water loss disintegration.

The irregular distribution of gypsum in the limestone formation aggravated the softening and swelling features of gypsum. According to the indoor expansion tests of lateral confinement on anhydrite in the Dugongling tunnel [21], the expansion forces of the specimens with anhydrite content are greater than $90 \%$ reaching $1.94-3.1 \mathrm{MPa}$, as shown in Figure 17. The existence of anhydrite made the swelling characteristics of the surrounding rock more significant. 


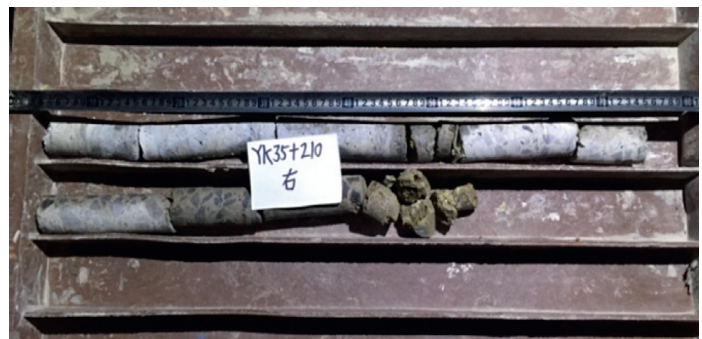

Figure 15: Core samples from the surrounding rock and concrete.

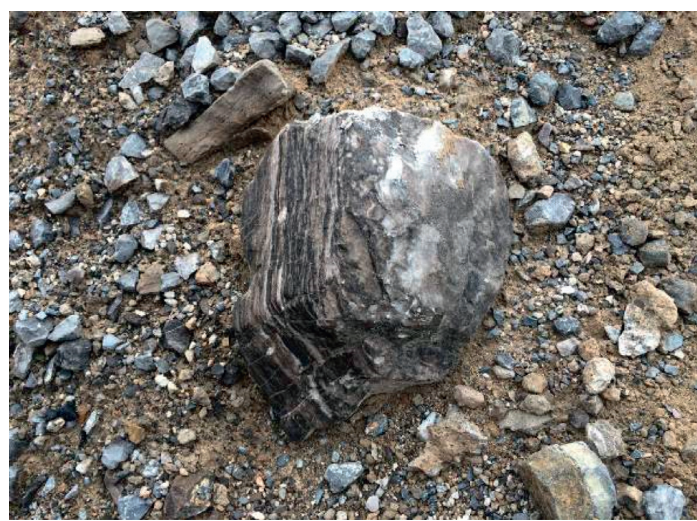

Figure 16: Gypsum rocks in the abandoned dreg site of the tunnel.

TABLE 4: Test results of marlstone [26].

\begin{tabular}{|c|c|c|c|c|c|c|c|c|}
\hline No. & $\begin{array}{l}\text { Drilling } \\
\text { number }\end{array}$ & Locations & $\begin{array}{c}\text { Free } \\
\text { expansion rate } \\
\text { Fs (\%) }\end{array}$ & $\begin{array}{c}\text { Expansion } \\
\text { force Pp }(\mathrm{kPa})\end{array}$ & $\begin{array}{l}\text { Saturated water } \\
\text { absorption rate } \\
\omega \text { sr }(\%)\end{array}$ & $\begin{array}{c}\text { Natural } \\
\text { compressive } \\
\text { strength }(\mathrm{MPa})\end{array}$ & $\begin{array}{c}\text { Saturated } \\
\text { compressive } \\
\text { strength (MPa) }\end{array}$ & $\begin{array}{c}\text { Softening } \\
\text { coefficient, } \delta\end{array}$ \\
\hline 1 & ZK5 & $\mathrm{K} 34+953$ & - & 1.5 & 5.2 & 26.9 & 22.0 & 0.818 \\
\hline 2 & ZK19 & $\mathrm{K} 35+370$ & 0.001 & 4.13 & 6.00 & 20.4 & 16.2 & 0.794 \\
\hline 3 & ZK4 & $\mathrm{K} 34+822$ & 0.006 & 0.99 & 4.60 & 12.0 & 9.0 & 0.75 \\
\hline 4 & ZK15 & $\mathrm{K} 35+155$ & 0.094 & 20.6 & 2.90 & 29.6 & 21.5 & 0.726 \\
\hline
\end{tabular}

Marlstone and gypsum rock softened and swelled under the action of groundwater. On the one hand, the softening of the surrounding rock of the tunnel reduced the bearing capacity of the surrounding rock. On the other hand, the swelling of the surrounding rock produced lateral expansion forces, both of which deteriorated the stress condition and load of supporting and lining structures. The variations of marlstone and gypsum rock along the longitudinal direction of the tunnel were superimposed on the unfavorable conditions of surrounding rock fragmentation, crack development, and karst, which caused the inhomogeneous distribution of loads on the supporting and lining structures longitudinally and laterally, resulting in the longitudinal cracking of the tunnel sidewall, the overturning of cable trenches, and uplifting of pavement.

4.5. Results of the Analysis of Tunnel Disease Causes. Surface pits provided favorable objective conditions for groundwater replenishment. Joint fissures and karst bodies (dissolved pores, caverns, and caves) developed in the rock mass and then provided paths for the circulation of groundwater. The composite fold structure and the water barrier formed by marl made the groundwater converge behind the tunnel section lining and kept accumulation. It dissolved and carried a large amount of sulfate ions and carbonate ions when the water flowed through, which was prone to thaumasite sulfate attack in the low temperature. In summary of various factors, the formation of tunnel diseases can be described in Figure 18 as follows.

\section{Engineering Treatment Plan}

According to the causes of tunnel diseases, the treatment of tunnel diseases can be done in the following aspects: groundwater treatment, surrounding rock reinforcement, and lining structure optimization.

5.1. Groundwater Treatment. According to the geological and hydrogeological conditions of the engineering project and the influence of groundwater in tunnel diseases, the treatment of groundwater mainly included programs as follows: 
TABLE 5: Identification results of core samples of the surrounding rock.

\begin{tabular}{|c|c|c|}
\hline No. & Test items & Test results/descriptions \\
\hline 1 & Name of rock sample & Anhydrite rock \\
\hline 2 & $\begin{array}{c}\text { Naked-eye observation on } \\
\text { color }\end{array}$ & Grey-white \\
\hline 3 & Sample preparation & Thin slice \\
\hline 4 & Structure & Fibrous structure, metasomatic residual structure \\
\hline 5 & Tectonics & Bedded \\
\hline 6 & Identification basis & GB/T17412.1 \\
\hline 7 & Essential mineral & $90 \%$ gypsum \\
\hline 8 & Secondary minerals & $4-6 \%$ dolomite and $4-6 \%$ anhydrite \\
\hline 9 & Accessory mineral & Zircon \\
\hline 10 & Microscopic observation & $\begin{array}{l}\text { The rock has a bedded tectonics, a fibrous structure, and a metasomatic residual structure. Gypsum is } \\
\text { fibrous. The protrusion is low and negative, and the highest interference color is first-order yellow and } \\
\text { white, and is arranged in a directional arrangement. Anhydrite is columnar, and most of it is converted } \\
\text { into gypsum, and a small amount of residue can be seen in the center of the crystal. The protrusion is } \\
\text { middle and positive, the highest interference color reaches third-order green, and it exhibits parallel } \\
\text { extinction and polysynthetic twin development with a directional arrangement. Dolomite has an } \\
\text { allotriomorphic granular structure with a particle size distribution of } 0.005-0.02 \mathrm{~mm} \text {, and it has a } \\
\text { prominent twinkling and high-order white interference color. }\end{array}$ \\
\hline
\end{tabular}

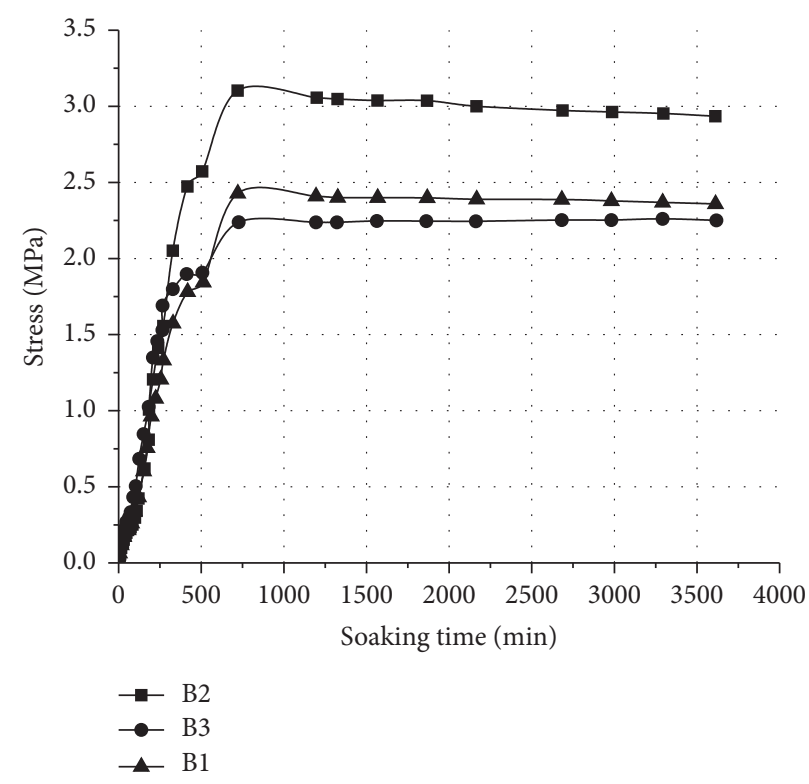

FIgURE 17: Expansive force test results of gypsum rock [21].

(1) Surface mine pits were backfilled and sealed to prevent the surface water collection and irrigation through the pits

(2) Grouting in the surrounding rock was adopted in the fracture zone and section of the tunnel to block the collection of groundwater behind the tunnel lining structure

(3) The section with all-inclusive waterproofing secondary lining where tunnel lining was replaced cut off the contact between the secondary lining of the tunnel and the groundwater

(4) The tunnel waterproof and drainage systems were improved and restored to avoid long-term collection and retention of groundwater in the tunnel
5.2. Surrounding Rock Reinforcement in the Tunnel. According to the softening and swelling characteristics of the surrounding rock of the tunnel and the development of karst, the reinforcement design of the tunnel surrounding rock was carried out, including the following:

(1) Long and short anchor rods were conducted in the tunnel to enhance the self-bearing capacity of the tunnel and control the expansion and deformation of the surrounding rock

(2) The karst development sections were filled and compacted by backfilling and grouting methods to enhance the bearing capacity and stability of the surrounding rock of the tunnel 


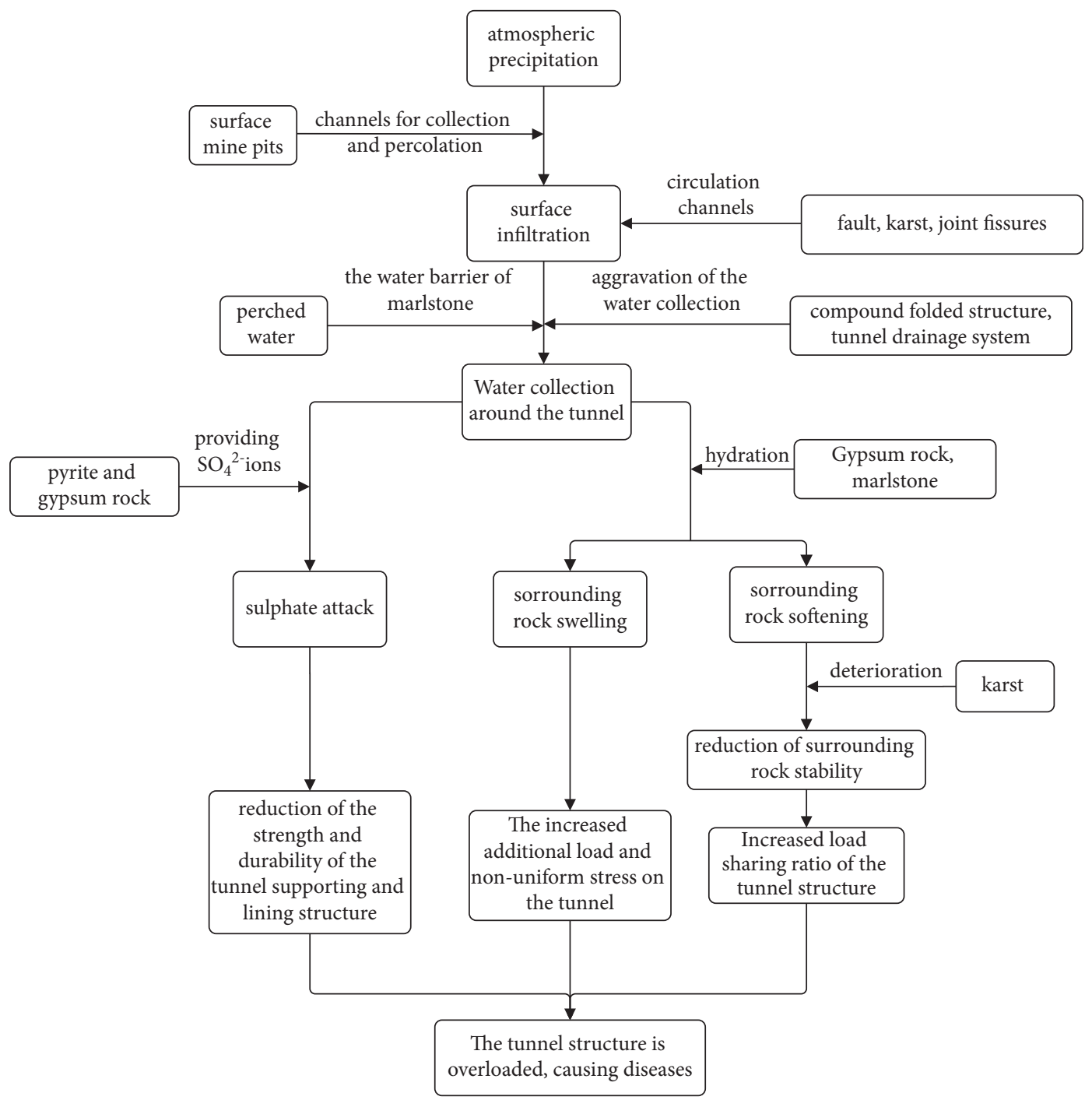

FIGURE 18: Mechanism of engineering harmfulness in the Dugongling tunnel.

5.3. Treatment of the Tunnel Lining Structure. According to the characteristics of the tunnel lining structure disease and the swelling and softening of the surrounding rock, the lining structure of the diseased section of the tunnel was treated as follows:

(1) The primary supporting and secondary lining replacement programs were adopted for the tunnel concrete under sulfate attacks. To improve the strength and load-bearing capacity of the tunnel, the supporting and lining structures were enclosed into a ring, of which the initial supporting was reinforced by I20 steel framework with a spacing of $60 \mathrm{~cm}$ and C30 shotcrete with a thickness of $28 \mathrm{~cm}$, and the secondary lining adopted a C35 reinforced concrete structure with a thickness of $50 \mathrm{~cm}$ (Figure 19).

(2) Design for sulfate attack resistance of the lining structure concrete: the occurrence of TSA needs many factors and complex mechanisms [27-30]. From the perspective of engineering applications, measures including waterproofing and reducing the source of sulfate ions were taken to prevent this disease. The measures can be summarized as "blocking the flow of $\mathrm{CO}_{3}^{2-}$, improving the impermeability of concrete structures, and decreasing the diffusion of external ions and groundwater." The detailed programs are as follows:

(i) The cement, coarse and fine aggregates, and external additives in the primary supporting concrete of the tunnel contained no limestone materials. The basalt was used as gravel by replacing limestone.

(ii) Admixtures in concrete (including preservatives, water-reducing agents and other additives, fly ash, and other admixtures) contained or produced no carbonate ions and sulfate ions.

(iii) The impermeability grade of the initial supporting concrete was greater than P6, preferably greater than $\mathrm{P} 8$, and the impermeability grade of the secondary lining concrete was greater than P8. 


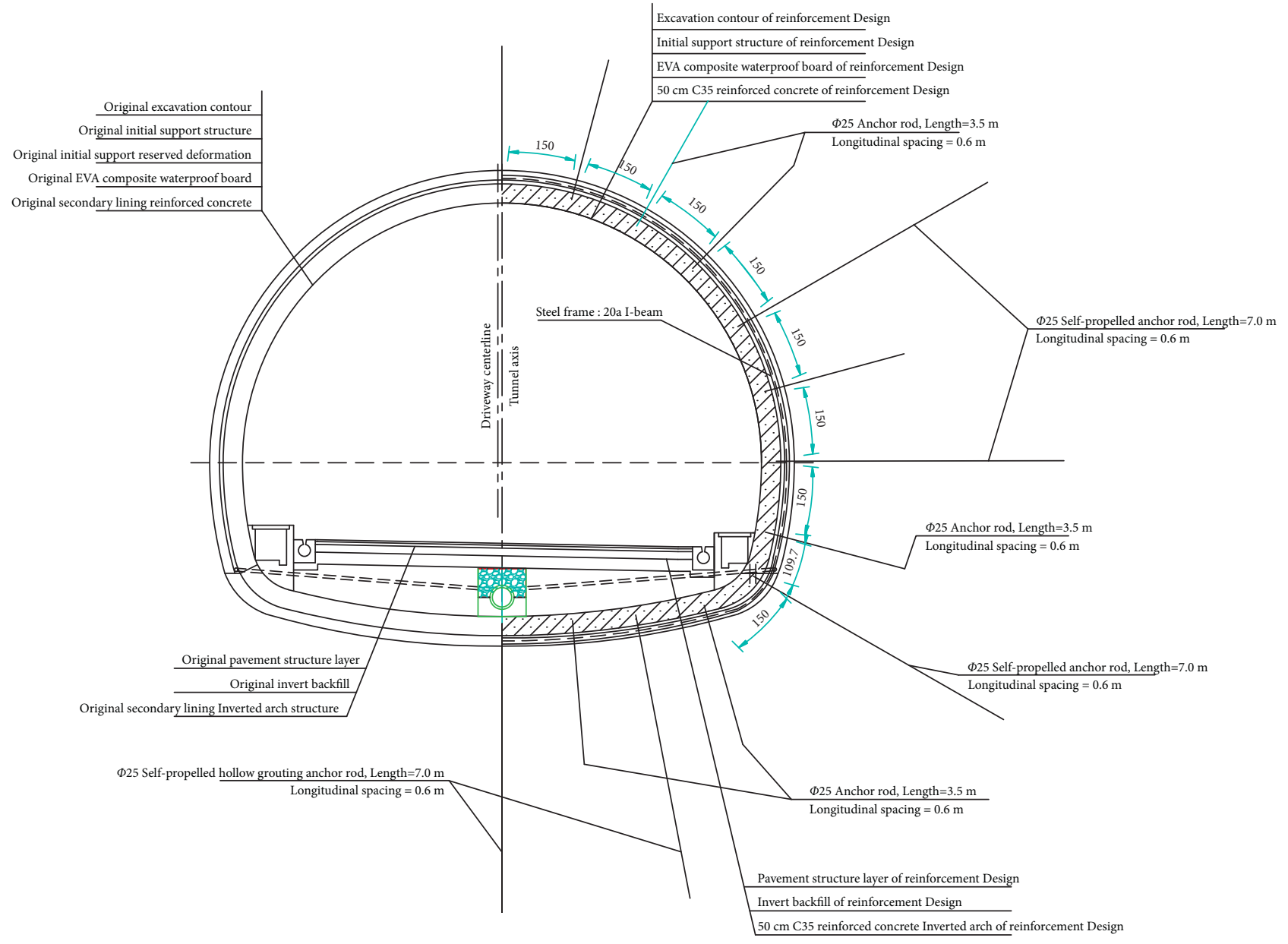

FIGURE 19: Schematic diagram of the treatment design of tunnel diseases.

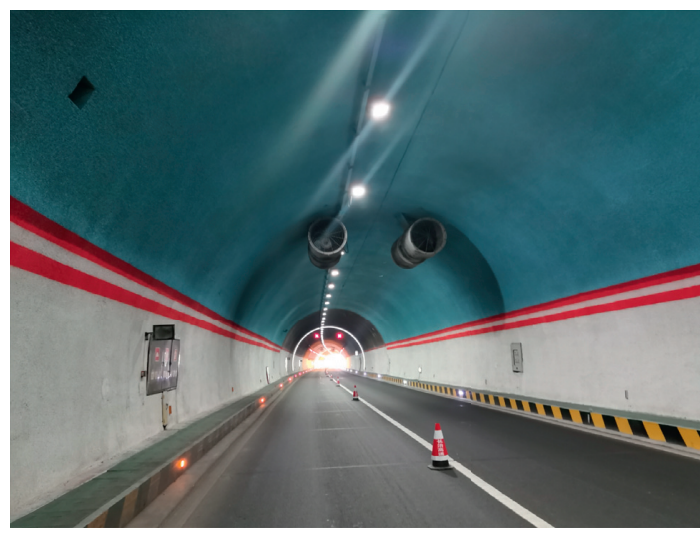

Figure 20: Photographs of the operation site of the Dugongling tunnel.

(iv) The sulfate-resistant concrete was used as the primary supporting and secondary lining concrete.

At present, the Dugongling tunnel has been opened to traffic for three years after the disease treatment, and the tunnel lining structure is in good technical condition (Figure 20).

\section{Conclusions}

(1) The disease of the Dugongling tunnel, mainly thaumasite sulfate attack, was a long cycle with multiple types and large scale. It took 6 years from the first discovery of the disease to the treatment of tunnel diseases. During this period, the diseases continued to develop, the number of disease types increased from the first 3 to 8 , and the outbreak of diseases occurred in the third year after construction (i.e., in 2014). The most serious disease, the lining structure collapse, took place in the fifth year after construction (i.e., in 2016).

(2) The formation process of the diseases: surface water was collected from surface mine pits and infiltrated underground, and then, it circulated to marlstone formation via karst caves, dissolution cavities, and joint fissures to form the perched water; under the influence of compound folded structure and the drainage system of the tunnel, groundwater was collected and infiltrated around the tunnel; the lowtemperature environment of the groundwater and the sulfate ions and carbonate ions in it caused TSAs to the tunnel lining structure, which deteriorated the 
strength and induced structural diseases of the tunnel lining structure; under the influence of groundwater, the surrounding rock of the tunnel softened and expanded, the load of the tunnel lining structure increased, and finally the lining cracked.

(3) Considering the formation conditions of TSA and the characteristics of the surrounding rock of the tunnel, the treatment measures of the tunnel diseases can [31-33] be proposed as "blocking the flow of $\mathrm{CO}_{3}^{2-}$, improving the impermeability of concrete structures, and decreasing the diffusion of external ions and groundwater."

\section{Data Availability}

The data used to support the findings of this study are available from the corresponding author upon request.

\section{Conflicts of Interest}

The authors declare no conflicts of interest.

\section{Acknowledgments}

This work was financially supported by the Central PublicInterest Scientific Institution Basal Research Fund (Grant no. 2020-9032) and the Science and Technology Project of Department of Transportation of Shanxi Province (Grant no. 2017-1-6).

\section{References}

[1] Y. R. Lu, F. E. Zhang, B. R. Yan, S. Zhang, and M. Yin, "Mechanism of karst development in sulphate rocks and its main geo-environmental impacts," Acta Geoscientia Sinica, vol. 23, no. 1, pp. 1-6, 2002.

[2] Y. M. Liu, H. M. Yu, and C. Wang, "Research on mechanism of damage of anhydrock in dolomite layer to tunnel structure," Rock and Soil Mechanics, vol. 32, no. 9, pp. 2704-2709, 2011.

[3] Z. R. Jia, Z. W. Li, and J. G. Dong, "Analysis and treatment measures of expansive surrounding rock of Liangshuijing tunnel," Highways, vol. 10, pp. 211-213, 2011.

[4] Y. B. Zhu, Y. L. Wu, and H. M. Yu, "Strength behavior of tunnel's gypsiferous surrounding rock," Journal of Yangtze River Scientific Research Institute, vol. 30, no. 9, pp. 53-58, 2013.

[5] X. K. Li, C. H. Shi, and M. F. Lei, "Defect classification of tunnel structures in sulfate environments," Modern Tunnelling Technology, vol. 4, pp. 19-24, 2011.

[6] M. Wu, Sulfate Resistance of Cement Based Materials in Low Temperature Environment, China University of Mining and Technology, Beijing, China, 2016.

[7] J. Y. Liu, Study on New Type of Antihigh Concentration Sulfate Corrosion Agent and its concrete Performance, Beijing University of Civil Engineering and Architecture, Beijing, China, 2016.

[8] F. Y. Peng, Study on Resistance of Alkali-Activated Slag Concrete to Sulfate Attack, Chongqing University, Chongqing, China, 2008.
[9] Z. Q. Liu, Study of the Basie Mechanisms of Sulfate Attack on Cementitious Materials, Central South University, Changsha, China, 2009.

[10] B. Erlin and D. C. Stark, Identification and Occurrence of Thaumasite in Concrete a Discussion for the 1965 HRB Symposium on Aggressive Fluids, Highway Research Record, Washington, DC, USA, 1966.

[11] D. Macphee and S. Diamond, "Thaumasite in cementitious materials," Cement and Concrete Composites, vol. 25, no. 8, pp. 805-807, 2003.

[12] M. Romer, L. Holzer, and M. Pfiffner, "Swiss tunnel structures: concrete damage by formation of thaumasite," Cement and Concrete Composites, vol. 25, no. 8, pp. 1111-1117, 2003.

[13] E. Freyburg and A. M. Berninger, "Field experiences in concrete deterioration by thaumasite formation: possibilities and problems in thaumasite analysis," Cement and Concrete Composites, vol. 25, no. 8, pp. 1105-1110, 2003.

[14] P. Hagelia, R. G. Sibbick, N. J. Crammond, and C. K. Larsen, "Thaumasite and secondary calcite in some Norwegian concretes," Cement and Concrete Composites, vol. 25, no. 8, pp. 1131-1140, 2003.

[15] F. Mittermayr, A. Baldermann, C. Kurta et al., "Evaporation a key mechanism for the thaumasite form of sulfate attack," Cement and Concrete Research, vol. 49, pp. 55-64, 2013.

[16] M. Y. Hu, M. S. Tang, and F. M. Long, "Thaumsite sulfate attack in concrete of Yongan Dam," Concrete, vol. 11, pp. 5-7, 2004.

[17] B. Ma, X. Gao, E. A. Byars, and Q. Zhou, "Thaumasite Formation in a tunnel of bapanxia dam in Western China," Cement and Concrete Research, vol. 36, no. 4, pp. 716-722, 2006.

[18] M. Y. Hu, F. M. Long, and M. S. Tang, "The thaumasite form of sulfate attack in concrete of Yongan Dam," Cement and Concrete Research, vol. 36, no. 10, pp. 2006-2008, 2006.

[19] A. Neville, "The confused world of sulfate attack on concrete," Cement and Concrete Research, vol. 34, no. 8, pp. 1275-1296, 2004.

[20] P. Fredrik, F. D. Glasser, and J. Marchand, "Durability of concrete-degradation phenomena involving detrimental chemical reactions," Cement and Concrete Research, vol. 38, no. 2, pp. 226-246, 2008.

[21] C. B. Xu and H. L. Wang, "Analysis on geological characteristics of gypsiferous marl strata in tunnel," Chinese Journal of Underground Space and Engineering, vol. 16, no. 1, pp. 227-233, 2020.

[22] C. Xu, X. Gao, K. Zhang, Z. Liu, and F. Zhao, "Constitutive model of swelling gypsum rock," Advances in Civil Engineering, vol. 2020, p. 1, Article ID 8878005, 2020.

[23] X. Y. Hao, P. L. Wang, and C. B. Xu, "Study on sulfate attack and treatment technology in tunnel," Modern Tunnelling Technology, vol. 56, no. S2, pp. 706-711, 2019.

[24] D. C. Wang, R. Q. Zhang, Y. H. Shi, S. Z. Xu, Q. C. Yu, and X. Liang, General Hydrogeology, Geological Publishing House, Beijing, China, 1997.

[25] H. B. Bai and X.-X. Miao, "Research on main controlling factors of ordovician karst development in Lu' an Coal Field," Journal of Mining \& Safety Engineering, vol. 25, no. 1, pp. 17-21, 2008.

[26] N.-N. Lang, Experimental Study and Application of Physical and Mechanical Properties of gypsum-containing Marl in Dugongling Tunnel, R esearch Institute of Highway Ministry of Transport, Beijing, China, 2018.

[27] X. J. Gao, B. G. Ma, and H. W. Deng, "Influence of binder composition on the thaumasite form of sulfate attack of 
concrete," Journal of Harbin Institute of Technology, vol. 39, no. 10, pp. 1554-1558, 2007.

[28] C. Wang, C. Yu, Y. L. Luo, and J. Liu, "Comparison of thaumasite sulfate attack formation speed under different erosion condition," Journal of Tongji University, vol. 43, no. 5, pp. 748-753, 2015.

[29] M. Wu, Y. S. Ji, X. F. Chen et al., "Effects of Superfine fly ash on thaumasite form of sulfate attack," Journal of Zhejiang University, vol. 50, no. 8, pp. 1479-1485, 2016.

[30] B. G. Ma, Z. T. Luo, X. J. Gao, and X. Li, “Thaumasite form of sulfate attack on different variety of cement," Journal of the Chinese Ceramic Society, vol. 34, no. 5, pp. 622-625, 2006.

[31] J. B. Wang, "The chemical action of karst water compositions of the Ordovician in Lu'an mine area," Coal Geology \& Exploration, vol. 27, no. 2, pp. 39-42, 1999.

[32] Y. L. Wu, The Engineering Geological Characteristics of gypsum Rock and the Damage Mechanism on Tunnel concrete Structure, China University of Geosciences, Wuhan, China, 2013.

[33] C. B. Xu and H. L. Wang, "Analysis on geological characteristics and its engineering harmfulness of dugongling tunnel," Journal of Highway and Transportation Research and Development, vol. 36, no. 8, pp. 93-100, 2019. 